\title{
MANAJEMEN PENGEMBANGAN MUTU SEKOLAH
}

\author{
Oleh : \\ Asep Priatna \\ STKIP Subang \\ (e-mail : aseppriatna064@gmail.com )
}

\begin{abstract}
ABSTRAK
Penelitian bertujuan untuk mengkaji "Manajemen Pengembangan Mutu Sekolah" khususnya dalam mengkaji faktorfaktor kepemimpinan kepala, fasilitas belajar, pendanaan dan partisipasi masyarakat terhadap implementasi rencana stratejik sekolah, dan pengembangan mutu sekolah pada Sekolah Menengah Pertama. Pendekatan dalam penelitian ini menggunakan kuantitatif, dengan metode survey dengan penjelasan yang mendalam (explanatory survey method), responden dalam penelitian ini adalah kepala sekolah, guru yang memperoleh tugas tambahan sebagai wakil kepala sekolah dan pengurus komite sekolah, dengan jumlah keseluruhan sebanyak 245 orang yang tersebar pada 35 sekolah menengah pertama (SMP) di Kabupaten Subang, yang memiliki akreditasi A dan B. Penjaringan data menggunakan kuesioner dan dianalisis menggunakan analisis korelasi ganda (multiple correlation analysis). Hasil penelitian menunjukkan bahwa kepemimpinan kepala sekolah memberikan kontribusi yang positif dan signifikan terhadap peningkatan mutu sekolah, implementasi rencana stratejik sekolah berkontribusi secara positif dan signifikan terhadap peningkatan mutu sekolah, fasilitas belajar berkontribusi secara positif dan signifikan terhadap peningkatan mutu sekolah, pendanaan berkontribusi secara positif dan signifikan terhadap peningkatan mutu sekolah, partisipasi masyarakat berkontribusi secara positif dan signifikan terhadap peningkatan mutu sekolah.
\end{abstract}

Kata kunci : Fasilitas Belajar, Implementasi Rencana Stratejik Sekolah, Kepemimpinan Kepala Sekolah, Manajemen Pengembangan Mutu Sekolah, Pendanaan Dan Partisipasi Masyarakat.

\begin{abstract}
The study aimed to assess the "Quality Development Management School" especially in studying factors leadership, learning, funding and participation to the implementation of the strategic plan school and junior high school quality development in Subang. The approach in this study used quantitative survey methods with in-depth explanation (explanatory survey method), the respondents in this study is the principal, teachers gained additional duties as viceprincipals and administrators of the school committee, for a total of as many as 245 people were scattered at 35 junior high school (SMP) in Subang district, which has accreditation A and B. Networking data using questionnaires and analyzed using multiple correlation analysis (multiple correlation analysis). The results showed that the principal's leadership provides a positive and significant contribution to improving the quality of schools, the implementation of the school's strategic plan to contribute positively and significantly to improving the quality of schools, learning facilities contribute positively and significantly to improving the quality of school, funding contribute positively and significantly to improving the quality of schools, the participation of the community in a positive and significant contribution towards improving the quality of the school.
\end{abstract}

Keywords : Funding And Community Participation, Implementation of The Strategic Plan Schools, Principal Leadership, Learning Facilities, Quality Development Management School.

\section{PENDAHULUAN}

Pendidikan merupakan sebagian dari kehidupan masyarakat yang memiliki peran sangat strategis dalam pengembangan kualitas sumber daya manusia. Pendidikan memiliki peran penting dalam menyiapkan dan merekayasa arah perkembangan masyarakat Indonesia masa depan. Pendidikan mempunyai peranan yang sangat besar dalam membangun bangsa, karena melalui pendidikan akan dapat dihasilkan sumberdaya manusia yang unggul. Kualitas pendidikan merupakan hal yang sangat penting seiring dengan penggunaan sumber daya pendidikan dan hasil yang diharapkan (Guthrie, 1984:790).
Berbagai studi yang dilaksanakan oleh berbagai pihak, menunjukkan bahwa kualitas pendidikan Indonesia masih rendah. Sehingga perkara rendahnya kualitas pendidikan menjadi salah satu isu kritis (critical or strategic issues) pendidikan nasional Indonesia. Keberhasilan manajemen pendidikan adalah kualitas pendidikan yang dapat diamati dari capaian prestasi baik akademik maupun non akademik, serta efektifitas dan efisiensi proses pendidikan. Artinya, kualitas pendidikan dapat dilihat dari prestasi, efektivitas dan efisiensi proses pendidikan yang dilaksanakan oleh lembaga pendidikan. Beberapa hal yang 
berpengaruh diantaranya kurikulum, tenaga pendidik dan kependidikan, siswa, bahan ajar, alat bantu pembelajaran, teknologi, ketersediaan sarana dan prasarana pendidikan, kondisi lingkungan fisik maupun psikis, managemen sekolah, serta kendali mutu.

Tingkat capaian mutu pendidikan secara umum dipengaruhi banyak faktor. Pengaruh itu dapat dikelompokan menjadi dua golongan yakni yang berasal dari dalam lingkungan sekolah, yaitu faktor kepemimpinan kepala sekolah, guru, kurikulum, sarana dan prasarana dan yang berasal dari luar sekolah, yaitu faktor eksternal sekolah, kebijakan dan dukungan masyarakat. Kehadiran kedua faktor itu berbeda pada sekolah yang satu dengan sekolah yang lain tingkat pengaruhnya terhadap mutu sekolah.

Berdasarkan data dari Pusat Penilaian Pendidikan Puslitbang Kemendiknas diatas, menunjukkan bahwa kualitas pendidikan di Kabupaten Subang masih belum optimal baik ditingkat Propinsi Jawa Barat maupun di tingkat nasional. Hal ini disebabkan karena sekolah belum mampu mengoptimalkan dan memanfaatkan segala sumber daya yang dimiliki untuk menjamin semua siswa bisa mempelajari materi kurikulum yang esensial di sekolah Taylor(Jalal, 2008).

Berdasarkan hasil kajian Research Improvement School didapatkan berbagai dimensi effective school sebagai sekolah unggul diantaranya adalah dimensi leadership, dimensi pendukung diantaranya rencana stratejik dan koordinasi. Sementara itu jika dijabarkan lebih lanjut, maka dimensi leadership, dimensi efisiensi dan efektivtas ditentukan oleh beberapa factor diantaranya perencanaan dan kebijakan sekolah berupa rencana stratejik, kepemimpinan kepala sekolah, fasilitas belajar, pendanaan dan partisipasi masyarakat.

Bahkan Cheng (Jalal, 2008) menyebutkan "school effectiveness as the capability of the school to maximize school functions or the degree to which the school can perform school functions, when given a fixed amount of school inputs", maksudnya adalah kemampuan sebuah sekolah untuk memaksimalkan fungsi sekolah atau sejauh mana sekolah dapat melakukan fungsi sekolah, ketika diberi jumlah input yang tetap pada sekolah tersebut.

Implementasi perencanaan stratejik sekolah, kepemimpinan kepala sekolah, fasilitas belajar, pendanaan dan partisipasi masyarakat tidak hanya ditunjukkan berupa capaian prestasi akademik, akan tetapi termasuk juga prestasi non-akademik yang cenderung rendah. Murphy dan Cleveland (1991:92) menyatakan bahwa : Job Performance should be defined in term of behavior or in term of the results of behavior. Dari uraian di atas tampak bahwa permasalahan yang ada hubungannya dengan tema penelitian ini sangat kompleks. Aspek-aspek yang mencakup di dalamnya sangatlah luas dan mendalam, karena itulah dalam penelitian ini akan mencoba untuk melakukan penelitian terhadap pelaksanaan program pengembangan mutu sekolah yang telah dilaksanakan oleh SMP di Kabupaten Subang dalam meningkatkan mutu pendidikan, sehingga dapat memenuhi harapan semua stakeholder.

Penelitian terdahulu terkait mutu sekolah dikaitkan dengan nilai tambah yaitu bahwa nilai tambah merupakan alat ukur untuk mengukur kualitas pendidikan. Terkait pengukuran tersebut juga dikembangkan berbagai teknologi dan model statistik untuk mengetahui tingkat kualitas pendidikan(Brown, Mc Namara \& O Hara, 2016; Conway \& Murphy, 2013; Sloane et. Al, 2013 ). Penelitian ini berbeda dengan penelitian yang melihat kualitas pendidikan dari sisi nilai tambah yang dihasilkannya, melainkan dari aspek pengembangannya.

Dalam pengembangan sumber daya manusia, pendidikan memegang peranan kunci sebagai pendekatan dasar dan bagian penting dalam suprasistem pembangunan bangsa. Pendidikan mempunyai peranan yang penting dalam pengembangan sumber daya manusia (Cohn, Elchanan 1979:16). Pendidikan berpengaruh terhadap produktivitas, tetapi juga berpengaruh terhadap fertilitas masyarakat. Pendidikan menjadikan sumber daya manusia lebih cepat mengerti dan siap dalam menghadapi perubahan-perubahan dalam kehidupannya. Ketersediaan manusia bermutu yang menguasai iptek sangat menentukan kemampuan bangsa dalam memasuki kompetensi global dan ekonomi pasar bebas, yang menuntut daya saing tinggi.

Mutu pendidikan menjadi salah satu tantangan dan persoalan bidang pendidikan dalam mewujudkan kualitas pendidikan dan sumberdaya yang bermutu. Pembahasan mutu pendidikan menjadi pemikiran yang tidak pernah berkesudahan sesuai dengan perkembangan pemikiran manusia. Mutu merupakan gambaran karakteristik menyeluruh dari sebuah produk barang maupun layanan jasa yang sesuai dengan harapan pelanggan, sehingga produk dan layanan tersebut dapat memuaskan pelanggannya (Depdiknas, Dikdasmen, 2001:4).

Upaya-upaya peningkatan mutu pendidikan, pengelolaannya menekankan kepada 
kemandirian dan kreativitas sekolah di dalam mengolah potensi sumber daya pendidikan melalui kerja sama dengan pernerintah dan masyarakat di dalam pengambilan keputusan untuk memenuhi tujuan peningkatan mutu sekolah. Untuk ini sekolah harus mampu menterjemahkan dan menangkap esensi kebijakan makro pendidikan serta memahami kondisi lingkungannya (kelebihan dan kekurangannya) untuk kemudian melalui proses perencanaan, sekolah harus rnemformulasikannya ke dalam kebijakan mikro dalam bentuk program-progrann prioritas yang harus dilaksanakan dan dievaluasi oleh sekolah sesuai dengan visi dan misinya masing-masing. Untuk mencapai mutu pendidikan yang diharapkan perlu dilakukan upaya $\neg$ upaya yang strategis sehingga mampu memberikan pelayanan dan produktivitas pendidikan kepada yang berkepentingan (stakeholder).

Salah satu aspek dalam manajemen yang memegang peranan penting dalam pengembangan mutu pendidikan adalah perencanaan stratejik. Manajemen strategik menurut Igor Ansoff \& Edward J. Mc Donnell (1990) adalah suatu pendekatan yang sistematis terhadap suatu perubahan tanggung jawab besar para manajer utama, bagaimana menempatkan dan menyesuaikan organisasinya supaya berhasil secara meyakinkan dalam menghadapi lingkungan yang berubah cepat, sehingga organisasinya survive. Disamping penyesuaian terhadap perubahan lingkungan organisasi, dalam manajemen strategik terkandung upaya-upaya berupa pembuatan (formulating), penerapan (implementing) dan evaluasi (evaluating) tentang keputusan-keputusan strategis antar fungsi-fungsi yang memungkinkan sebuah organisasi mencapai tujuan-tujuan masa mendatang (Wahyudi, 1996; Hunger \& Wheelen, 1999). Proses manajemen strategik adalah cara yang akan dilakukan para penyusun strategi menentukan tujuan-tujuan dan juga membuat keputusan-keputusan strategic (Nawawi, 2003; Certo and Peter, 2002). Keputusan strategik adalah juga alat untuk mencapai tujuan. Keputusan ini meliputi definisi bisnis, produk yang dibuat, pasar yang dilayani, fungsi-fungsi yang dilaksanakan dan kebijaksanaan-kebijaksanaan utama yang diperlukan perusahaan untuk melaksanakan keputusan-keputusan tadi agar tujuan perusahaan dapat dicapai.

Implementasi rencana stratejik sekolah merupakan penjabaran operasional dari visi, misi, dan tujuan sekolah yang telah disusun bersama oleh segenap komponen sekolah yang dibuat berdasarkan model pendekatan pengembangan sekolah seutuhnya secara terarah dan terpadu dalam rangka meningkatkan mutu lulusan dan kualitas sekolah secara keseluruhan. Implementasi rencana stratejik sekolah yang biasa diwujudkan dalam RIPS mesupakan hasil kerja dari segenap komponen sekolah dalam memberikan kontribusi sebagai kerja kolektif.

Mutu belajar-mengajar di sekolah sangat ditentukan oleh keberadaan kepala sekolahnya. Sehingga dapat dikatakan bahwa semakin berkwalitas kepemimpinan kepala sekolah, maka semakin baik mutu sekolah yang dipimpinnya. Hal ini sejalan dengan pendapat yang dikemukakan oleh Mortimer J. Adler (Permadi: 1998: 24), yang menyatakan "The quality of teaching and learning that goes in a school is largely determined by the quality of principals leadership" Telah dikemukakan bahwa sebagai penanggungjawab dalam penyelenggaraan proses belajar mengajar di sekolah, kepala sekolah mempunyai fungsi-fungsi sebagai edukator, manager, adminitrator dan supervisor.

Fungsi kepemimpinan merupakan salah satu fungsi dalam manajemen yang tidak bisa terpisahkan. Kepemimpinan tidak hanya sekedar memerintah, menghukum, dan menyuruh, akan tetapi lebih dari itu, kepemimpinan adalah seni dalam memerankan seorang pemimpin yang dapat melaksanakan transformasi kebijakan menjadi sebuah bentuk operasional, sehingga bentukbentuk perintah dan pengarahan dapat dimengerti dan dijalankan oleh bawahan. Paradigma baru manajemen pendidikan dalam rangka meningkatkan kualitas secara efektif dan efisien, perlu didukung oleh sumber daya manusia yang berkualitas. Paradigma pendidikan yang memberikan kewenangan luas kepada sekolah dalam mengembangkan berbagai potensinya memerlukan pengembangan kemampuan kepala sekolah dalam berbagai aspek manajerialnya, agar dapat mencapai tujuan sesuai dengan visi dan misi yang diemban sekolahnya.

Sarana dan prasarana merupakan sumber utama yang memerlukan penataan sehingga fungsional, aman, dan atraktif untuk keperluan proses-proses belajar di sekolah. Secara fisik sarana dan prasarana harus menjamin adanya kondisi higienik dan secara psikologis dapat menimbulkan minat belajar. Hampir dari separuh waktunya siswa-siswa bekerja, belajar, dan bermain di sekolah. Karena itu lingkungan sekolah (sarana dan prasarana) harus aman, sehat, dan menimbulkan persepsi positif bagi siswasiswanya.

Pendanaan pendidikan merupakan salah satu salah satu kajian dalam administrasi 
pendidikan, yang membicarakan mengenai bagaimana sumber biaya itu diperoleh dan bagaimana menggunakan biaya pendidikan yang diperoleh itu serta pertanggungjawaban terhadap penggunaan dana tersebut. Pendanaan pendidikan (educational finance) mencakup tiga aspek, yaitu: revenue (sumber dana); expenditure yang merupakan alokasi penggunaan dana yang diperoleh serta pertanggung jawaban (acuntability) atas penggunaan dana tersebut. Selanjutnya Idochi Anwar (1990; 50), menyatakan bahwa pendanaan pendidikan merupakan kegiatan dalam penyelenggaraan pendidikan yang menyangkut bagaimana upaya mencari sumber dana dan bagaimana menggunakan dana yang ada itu dalam proses penyelenggaraan

Untuk menciptakan pemberdayaan yang bermutu, seluruh pihak yang terkait; masyarakat, aparat pemerintah dan administrasi daerah pada semua tingkatan, serta staf dari sektor swasta atau sektor ketiga lainnya perlu dilibatkan dalam seluruh aspek pengembangan dan pelaksanaan program (Baker, 1998, Greg Wise 1998). Partisipasi masyarakat dalam dunia pendidikan mengisyaratkan adanya kerjasama dengan banyak pihak. Dalam kerjasama antara masyarakat dengan dunia pendidikan orang mengaktualisasikan diri dengan merealisasikan segenap kemampuannya. Partisipasi masyarakat dalam pengembangan pendidikan menurut Hamijoyo (1977) dapat diwujudkan dalam (1) buah pikiran, (2) ketrampilan, (3) tenaga, (4) harta benda, (5) uang atau materi, disamping itu juga dapat diwujudkan keterlibatannya dalam perencanaan, pelaksanaan, dan pengawasan program pendidikan.

Menurut Sewel (Wibawa, 2005: 47) terdapat berbagai strategi untuk meningkatkan partisipasi masyarakat dalam bidang pendidikan yaitu dengan (1) membuat rancangan kebijakan, (2) menginformasikan rancangan tersebut kepada masyarakat yang akan terlibat, (3) mengumpulkan tanggapan masyarakat tentang isi rancangan kebijakan, (4) memadukan pendapat masyarakat dengan rancangan kebijakan, (5) membuat kebijakan baru yang mengarah pada pelaksanaan.

$$
\text { Partisipasi masyarakat dalam }
$$

pengembangan pendidikan dapat dimanfaatkan oleh sekolah khususnya sebagai sebuah kekuatan dalam mengembangkan lembaga khsuusnya menjadi lembaga pendidikan yang mampu mengakomodir kebutuhan masyarakat. Sehingga partisipasi masyarakat dalam pengembangan pendidikan dapat diwujudkan dalam bentuk (1) keterlibatan masyarakat dalam program pendidikan, (2) keterlibatan masyarakat dalam pemberdayaan pendidikan, (3) keterlibatan masyarakat dalam pendanaan pendidikan, (4) keterlibatan masyarakat dalam mengembangkan kemandirian sekolah.

\section{- Kerangka Pemikiran}

Pada hakekatnya guru bukan satu-satunya penyebab rendahnya kualitas pendidikan., fakta menunjukkan dalam hal pilar pengembangan mutu, relevansi, dan daya saing, faktor sarana dan prasarana (ruang kelas, perpustakaan, laboratorium, dan lainnya), juga motivasi peserta didik dan peran orang tua/masyarakat memiliki andil yang sangat besar terhadap pencapaian mutu sekolah dan lulusan.

Mutu lulusan pendidikan sangat erat kaitannya dengan proses pelaksanaan pembelajaran yang dipengaruhi oleh banyak faktor, faktor-faktor tersebut dapat berasal dari faktor internal dan faktor eksternal. Beberapa faktor internal diantaranya kurikulum, tenaga pendidik, kepemimpinan kepala sekolah, proses pembelajaran, sarana dan prasarana, alat bantu dan bahan, manajemen, sekolah, dan lingkungan sekolah. Sementara faktor dari luar adalah dukungan masyarakat, dan kebijakan pendidikan yang mendukung pelaksanaan pendidikan. Keterkaitan antara faktor internal dan faktor eksternal sangat besar peranannya dalam mencapai tujuan pendidikan.

Khususnya dalam pengembangan sekolah beberapa faktor tersebut sangat menentukan pencapaian mutu dan keberhasilan sekolah dalam mencapai tujuan. Faktor internal memegang peranan dalam mengembangkan proses pelaksaan belajar mengajar disekolah, sementara faktor eksternal mendukung pencapaian program khususnya dalam pengadaan dan pemenuhan kebuthan sarana dan prasarana belajar.

Uraian yang dikemukakan sebelumnya memperlihatkan keterkaitan antara implementasi manajemen stratejik, kepemimpinan kepala sekolah, fasilitas belajar, pendanaan pendidikan, partisipasi masyarakat terhadap pengembangan mutu sekolah. Keterkaitan tersebut memperlihatkan model hubungan fungsional yang dapat digambarkan di bawah ini.

\section{- Hipotesis Penelitian}

Berdasarkan asumsi-asumsi tersebut, maka penulis merumuskan hipotesis penelitian yaitu :

- Kepemimpinan kepala sekolah berpengaruh positip terhadap implementasi rencana stratejik sekolah pada SMP di Kabupaten Subang Fasilitas belajar berpengaruh positip 
terhadap implementasi rencana stratejik sekolah pada SMP di Kabupaten Subang

- Pendanaan pendidikan berpengaruh positip terhadap implementasi rencana stratejik sekolah pada SMP di Kabupaten Subang

- Partisipasi masyarakat berpengaruh positip terhadap implementasi rencana stratejik sekolah pada SMP di Kabupaten Subang Jawa Barat

- Implementasi rencana stratejik sekolah berpengaruh positip terhadap pengembangan mutu sekolah pada SMP di Kabupaten Subang.

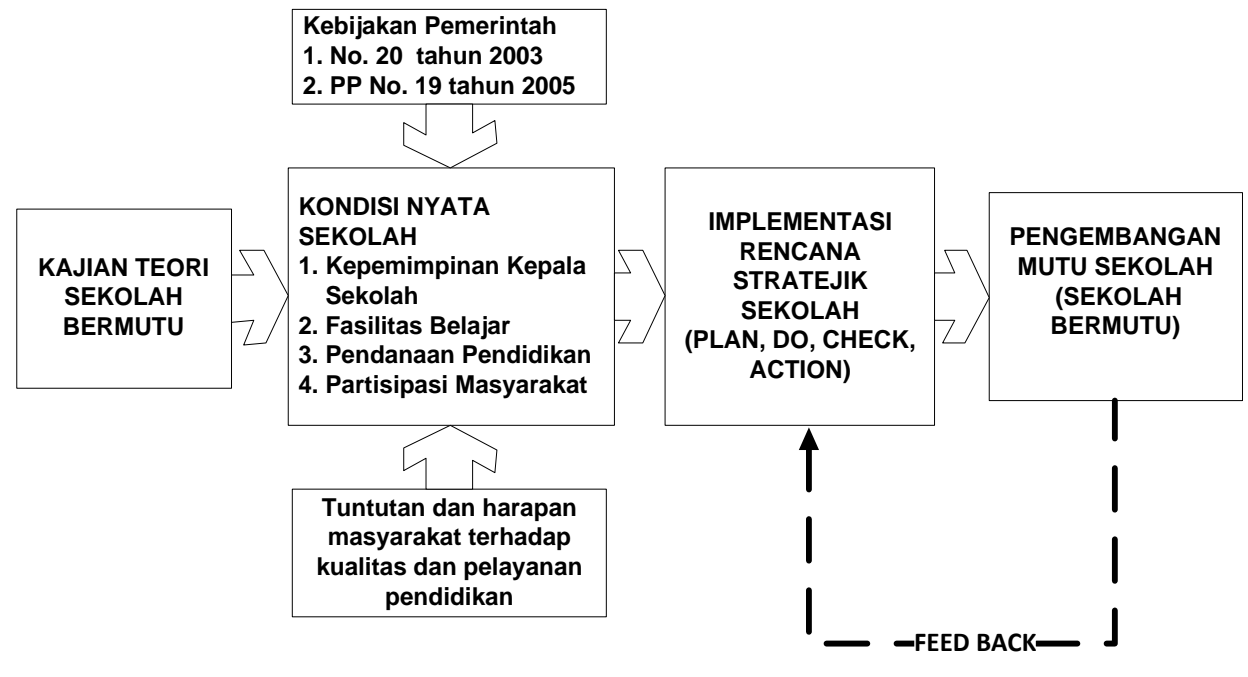

Gambar.1 Kerangka Pikir Penelitian

\section{METODE PENELITIAN}

Penelitian ini menggunakan metode penelitian survei dengan pendekatan kuantitatif. Penelitian survei yang dimaksud diharapkan dapat menjelaskan hubungan kausal dan pengujian hipotesis. Jenis penelitian survei ini memfokuskan pada pengungkapan hubungan kausal antar variabel, yaitu suatu penelitian yang diarahkan untuk menyelidiki hubungan sebab berdasarkan pengamatan terhadap akibat yang terjadi, dengan tujuan memisahkan pengaruh langsung dan pengaruh tidak langsung sesuatu variabel penyebab terhadap variabel akibat. Variabel sebab-akibat tersebut adalah variabel kepemimpinan kepala sekolah (X1), fasilitas belajar (X2), pendanaan (X3) dan partisipasi masyarakat $(\mathrm{X} 4)$ terhadap implementasi rencana stratejik sekolah (Y) dan pengembangan mutu sekolah (Z) pada SMP di Kabupaten Subang.

Karena data hasil penelitian berupa angka-angka yang harus diolah secara statistik, maka antar variabel-variabel yang dijadikan objek penelitian harus jelas korelasinya sehingga dapat ditentukan pendekatan statistik yang akan digunakan sebagai pengolah data yang pada gilirannya hasil analisis dapat dipercaya (reliabilitas dan validitas), dengan demikian mudah untuk digeneralisasikan sehingga rekomendasi yang dihasilkan dapat dijadikan rujukan yang cukup akurat.

Populasi dalam penelitian ini adalah kepala sekolah, guru dan komite sekolah yang ada di SMP di Kabupaten Subang sebanyak 171 SMP. Dalam penelitian ini yang digunakan sebagai sampel dan unit analisis adalah semua SMP yang telah mencapai akreditasi A dan B sebanyak 97 sekolah. Sebagai sampel dalam penelitian ini sebanyak 245 orang dipilih sebagai subyek penelitian yang terdiri dari 35 orang kepala sekolah dari 35 sekolah terpilih, 140 orang guru yang memiliki tugas tambahan sebagai wakil kepala sekolah, dan 70 orang pengurus komite sekolah yaitu ketua dan sekretaris komite pada masing-masing sekolah.

Data yang akan dikumpulkan dapat berupa angka-angka, keterangan tertulis, informasi lisan dan beragam fakta yang berhubungan dengan fokus penelitian yang diteliti. Sehubungan dengan pengertian teknik pengumpulan data dan wujud data yang akan dikumpulkan, maka dalam penelitian ini digunakan dua teknik utama pengumpulan data, yaitu studi dokumentasi dan teknik angket. Analisis data yang digunakaadalah path analysis. Analisis ini untuk mengetahui pengaruh 
kepemimpinan kepala sekolah, fasilitas belajar, pendanaan dan partisipasi masyarakat secara simultan berpengaruh yang signifikan terhadap implementasi rencana stratejik sekolah pada SMP di Kabupaten Subang baik secara bersama-sama maupun secara individu. Disamping itu juga digunakan untuk menguji pengaruh implementasi rencana stratejik terhadap pengembangan mutu sekolah pada SMP di kabupaten Subang.

\section{HASIL PENELITIAN}

Penelitian ini menjawab hipotesis yang diajukan, apakah diterima atau ditolak. Data yang diperoleh melalui penelitian ini dianalisis untuk menjelaskan pengaruh(sumbangan) antar variabel kepemimpinan kepala sekolah $\left(\mathrm{X}_{1}\right)$, fasilitas belajar $\left(\mathrm{X}_{2}\right)$, pendanaan $\left(\mathrm{X}_{3}\right)$, dan partisipasi masyarakat $\left(\mathrm{X}_{4}\right)$ terhadap implementasi rencana stratejik sekolah $(\mathrm{Y})$ dan pengembangan mutu sekolah (Z) pada SMP di Kabupaten Subang, beberapa temuan dalam penelitian ini diantaranya

- Diskripsi empirik variabel penelitian

- Berdasarkan data yang diperoleh dari 245 responden pada 35 sekolah, maka perilaku kepemimpinan kepala sekolah pada SMP di Kabupaten Subang tergolong 'sangat memadai'.

- Berdasarkan data yang diperoleh dari 245 responden pada 35 sekolah, maka fasilitas elajar pada SMP di Kabupaten Subang yang tergolong 'sangat memadai'.

- Berdasarkan data yang diperoleh dari 245 responden di Kabupaten Subang tergolong 'sangat memadai'.

- Berdasarkan data yang diperoleh dari 245 responden pada 35 sekolah, maka partisipasi masyarakat pada SMP di Kabupaten Subang tergolong 'sangat memadai'.

- Berdasarkan data yang diperoleh dari 245 responden pada 35 sekolah, maka implementasi rencana stratejik pada SMP di Kabupaten Subang tergolong 'sangat memadai'.

- Berdasarkan data yang diperoleh dari 245 responden, maka pengembangan mutu sekolah pada SMP di Kabupaten Subang tergolong 'memadai'.

\section{- Hasil uji hipotesis}

Penelitian ini menjawab hipotesis yang diajukan, apakah diterima atau ditolak. Data yang diperoleh melalui penelitian ini dianalisis untuk menjelaskan pengaruh (sumbangan) antar kepemimpinan kepala sekolah $\left(\mathrm{X}_{1}\right)$, fasilitas belajar $\left(\mathrm{X}_{2}\right)$, pendanaan $\left(\mathrm{X}_{3}\right)$ dan partisipasi masyarakat $\left(\mathrm{X}_{4}\right)$ terhadap implementasi rencana stratejik sekolah (Y) dan pengembangan mutu sekolah (Z) pada SMP di Kabupaten Subang. Hasil analisis data penelitian menunjukkan bahwa:

- Besarnya pengaruh kepemimpinan kepala sekolah terhadap implementasi rencana stratejik sekolah adalah $0,370^{2}=0,1369$ atau $13,69 \%$.

- Besarnya pengaruh fasilitas terhadap implementasi stratejik sekolah adalah $0,330^{2}$ $=0,1089$ atau $10,89 \%$.

- Besarnya pengaruh pendanaan terhadap implementasi rencana stratejik sekolah adalah $0,472^{2}=0,222$ atau $22,2 \%$.

- Besarnya pengaruh partisipasi masyarakat terhadap implementasi rencana stratejik sekolah adalah $0,600^{2}=0,3600$ atau $36,00 \%$.

- Besarnya pengaruh kepemimpinan kepala sekolah, fasilitas belajar pendanaan dan partisispasi masyarakat terhadap implementasi rencana stratejik sekolah adalah $0,758^{2}$ atau $75,8 \%$

- Besarnya pengaruh implementasi rencana strategic sekolah terhadap pengembangan mutu sekolah adalah $0,724^{2}=0,525$ atau $52,5 \%$.

Besarnya pengaruh kepemimpinan kepala sekolah $\left(\mathrm{X}_{1}\right)$ fasilitas $\left(\mathrm{X}_{2}\right)$, pendanaan $\left(\mathrm{X}_{3}\right)$, partisipasi masyarakat $\left(\mathrm{X}_{4}\right)$ terhadap implementasi rencana stratejik (Y) dan pengembangan mutu sekolah (Z) dan jawaban terhadap hipotesis penelitian yang diajukan tersebut di ringkas dalam tabel berikut:

Tabel 1.

Rangkuman Hasil Pengujian Hipotesis

\begin{tabular}{ccccc}
\hline \multirow{2}{*}{ Pengaruh } & \multicolumn{2}{c}{$\begin{array}{c}\text { Pengaruh kausal } \\
\text { Tidak langsung }\end{array}$} & \multirow{\varepsilon}{*}{ dan $\boldsymbol{\varepsilon}_{2}$} & Total \\
\cline { 2 - 4 } & Langsung & Melalui Y & - & 0.370 \\
\hline$X_{1}-\mathrm{Y}$ & 0.370 & - & -
\end{tabular}




\begin{tabular}{ccccc}
$\mathrm{X}_{2}-\mathrm{Y}$ & 0.330 & - & - & 0.330 \\
$\mathrm{X}_{3}-\mathrm{Y}$ & 0.472 & - & - & 0.472 \\
$\mathrm{X}_{4}-\mathrm{Y}$ & 0.600 & - & - & 0.600 \\
$\mathrm{X}_{1}, \mathrm{X}_{2}, \mathrm{X}_{3}, \mathrm{X}_{4}-\mathrm{Y}$ & 0.758 & - & 0,242 & 1,00 \\
$\mathrm{Y}-\mathrm{Z}$ & 0.425 & - & 0.525 & 1.00 \\
\hline
\end{tabular}

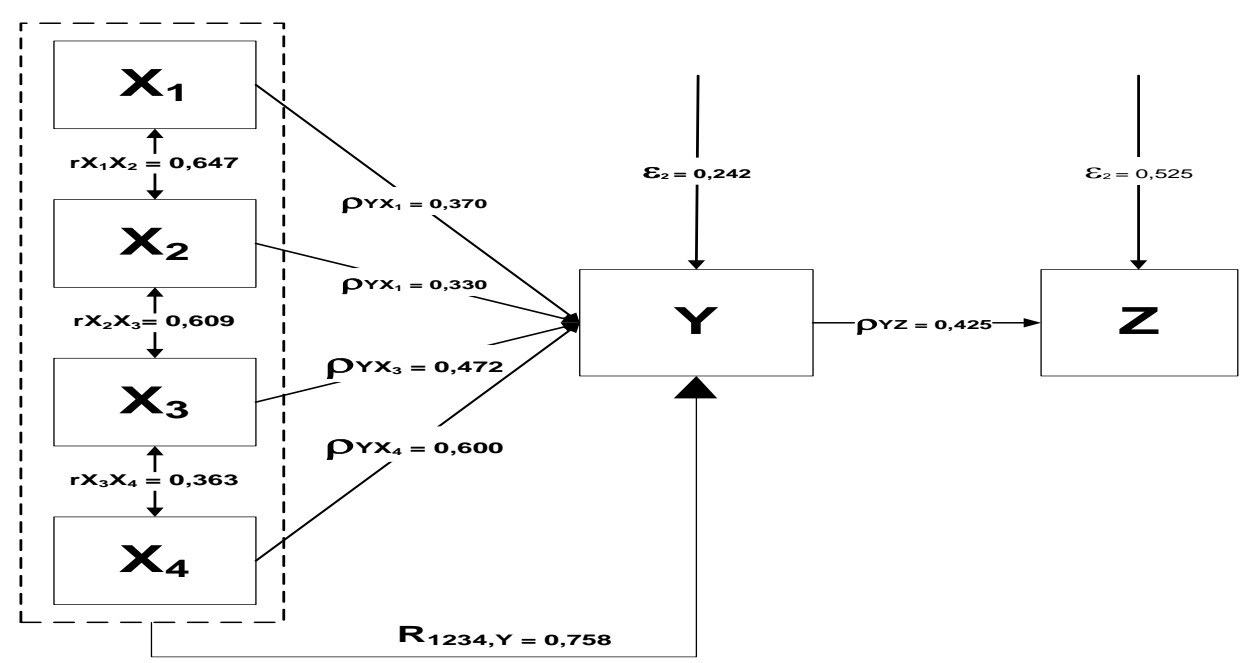

Gambar 2. Hasil Diagram Jalur Hubungan Kausal Empiris

\section{PEMBAHASAN}

Pengembangan mutu sekolah merupakan tugas dan tanggung jawab kepala sekolah, selaku pemimpin pendidikan. Namun demikian, pengembangan mutu sekolah mempersyaratkan adanya partisipasi seluruh personil sekolah dan stakeholder, termasuk orang tua siswa, dan oleh karena itu, secara manajerial pengembangan mutu sekolah menjadi tanggung jawab kepala sekolah, sedangkan secara operasional sehari-hari menjadi tugas seluruh personil sekolah dan stakeholder terkait.

Peningkatan dan pengembangan mutu sekolah memerlukan Kepala Sekolah yang mampu: (1) memandang bahwa sumber daya yang ada berguna sebagai penyedia dorongan yang memadai bagi guru-guru; (2) mencurahkan banyak waktunya untuk pengelolaan dan koordinasi proses instruksional, dan (3) berkomunikasi secara teratur dengan staf, orang tua, siswa dan anggota masyarakat dan sekitarnya, serta lembaga pendukung yang ada di luar institusi pendidikan itu sendiri.

Impelementasi rencana stratejik sekolah merupakan penjabaran operasional dari visi, misi, dan tujuan sekolah yang telah disusun bersama oleh segenap komponen sekolah yang dibuat berdasarkan model pendekatan pengembangan sekolah seutuhnya secara terarah dan terpadu dalam rangka meningkatkan mutu lulusan dan kualitas sekolah secara keseluruhan.
Implementasi rencana stratejik sekolah merupakan tugas dan tanggung jawab kepala sekolah, selaku pemimpin pendidikan. Namun demikian, implementasi rencana stratejik sekolah mempersyaratkan adanya partisipasi seluruh personil sekolah dan semua stakeholder, termasuk orang tua siswa, dan oleh karena itu, secara manajerial implementasi manajemen stratejik sekolah menjadi tanggung jawab kepala sekolah, sedangkan secara operasional sehari-hari menjadi tugas seluruh personil sekolah dan stakeholder terkait.

Kerangka kebijakan tingkat mikro yang tertuang dalam rencana induk pengembangan sekolah (RIPS) merupakan implementasi dari visi dan misi untuk mencapai tujuan sekolah dalam rangka mewujudkan "sekolah bermutu". Dalam penyusunan program pengembangan mutu, sekolah belum mampu melibatkan stakeholder sebagai mitra, padahal menurut David J. Hunger and Wheelen L. Thomas (1993) bahwa suatu visi agar menjadi realistik, dapat dipercaya, meyakinkan, serta mengandung daya tarik maka dalam proses pembuatannya perlu melibatkan semua stakeholder. Kendala yang dihadapi oleh sekolah dalam melibatkan stakeholder disebabkan oleh karena komunikasi aktif antara sekolah belum terjadi dengan baik, sehingga pihak sekolah perlu mengkomunikasikan program yang dimiliki kepada stakeholder dengan baik. 
Kepemimpinan kepala sekolah merupakan ujung tombak dan kemudi bagi jalannya lembaga pendidikan. Jika suatu lembaga pendidikan tanpa ada pemimpin yang adaptif dan kreatif, maka kurang optimal dalam pelaksanaannya atau kemunduran suatu lembaga pendidikan. Kepemimpinan kepala sekolah merupakan hal pokok dari aktifitas manajemen dalam menggerakkan potensi sekolah, kepemimpinan kepala sekolah juga merupakan salah satu penjelas yang paling populer untuk keberhasilan atau kegagalan sekolah.

Besarnya keterlibatan masyarakat dan stakeholder dalam program pengembangan mutu sekolah sebenarnya telah memperoleh keran yang cukup besar, yang menempatkan stakeholder dan masyarakat sebagai bagian dalam proses pendidikan yang berlangsung. Melalui keterlibatan ini diharapkan bahwa para stakeholder pendidikan mengambil peran yang maksimal, sehingga sekolah mampu memberikan yang terbaik bagi customernya.

\section{- Model Pengembangan Mutu Sekolah}

Berdasarkan hasil temuan dalam penelitian bahwa kepemimpinan kepala sekolah, fasilitas sekolah, pendanaan dan partisipasi masyarakat berkontribusi secara positif dan signifikan terhadap implementasi rencana stratejik sekolah dan pengembangan mutu sekolah baik secara langsung maupun tidak langsung. Hal ini memberikan pemikiran bahwa aspek tersebut sangat besar peranannya terhadap perencanaan dan pencapaian program pengembangan mutu sekolah, sehingga upaya pengembangan mutu sekolah membutuhkan komitmen dari semua pihak yang terlibat dalam pengelolaan sekolah dan semua stakeholder khususnya masyarakat.

Dalam mengembangkan mutu sekolah, semua stakeholder dituntut secara aktif berpartisipasi dalam perencanaan, pelaksanaan, pengawasan, evaluasi dan tindaklanjut program pengembangan mutu tersebut. Secara umum semua komponen sekolah baik pimpinan yang meliputi kepala sekolah, guru yang diberi tugas tambahan sebagai wakil kepala sekolah dan semua stakeholder juga khususnya partisipasi orangtua dalam mengembangkan mutu sekolah harus bersama-sama mengembangkan dan melaksanakan program yang terkordinasi dalam sebuah sistem manajemen sekolah.
Struktur model pengembangan mutu sekolah dibuat sebagai acuan dalam pengembangan dan pengembangan mutu pembelajaran serta proses pendidikan, sebagaimana dapat diamati pada gambar 4.8 dibangun melalui tiga komponen utama system manajemen yaitu input, proses dan output. Input memiliki beberapa komponen utama yang sangat dibutuhkan yaitu (1) kebijakan; kepemimpinan; (3) siswa; (4) fasilitas; (5) pendanaan;; (6) guru; (7) kurikulum dan (8) stakeholder. Proses meliputi semua kegiatan pengelolaan proses pendidikan dan strategi pencapaian mutu. Keterlibatan semua aspek dalam proses sangat menentukan keberhasilan program dan dampak terhadap pengembangan mutu sekolah. Sementara output yang diharapkan adalah pencapaian kualitas lulusan dan manajemen sekolah yang efektif dan efisien dalam memanfaatkan semua sumber daya yang dimiliki.

Sebagai sebuah acuan dalam mengembangkan mutu sekolah, model hipotetik ini diharapkan dapat diimplementasikan agar pencapaiannya dapat terukur dengan jelas dan tepat.. Tiga komponen dasar dari model hipotetik ini berupa (1) input; (2) proses; (3) output; masing-masing komponen dapat dijabarkan dalam strategi implementasi sebagai berikut:

Input pada model hipotetik pengembangan mutu sekolah ini lebih menitikberatkan pada kegiatan pemberdayaan semua sumber daya yang dimiliki oleh sekolah. Sejalan dengan itu pada Gambar 4.10 metode pengembangan dapat dipahami proses pengembangan dilakukan melaui kajian potensi dan peluang yang dimiliki sekolah dan dituangkan dalam sebuah kerangka kerja yang dapat dilaksanakan, sehingga indikator capaian semakin jelas.

Proses pada model hipotetik pengembangan mutu sekolah ini lebih menitik beratkan pada kegiatan penyusunan dan implementasi program pengembanagn sekolah yang dilakukan secara berkesimabungan dan terus-menerus. Hasil kajian teknis pengembangan mutu sekolah selanjutnya dapat dituangkan dalam bentuk rencana stratejik dan dilaksanakan dengan pengawasan dan monitoring oleh kepala sekolah secara terus menerus. 


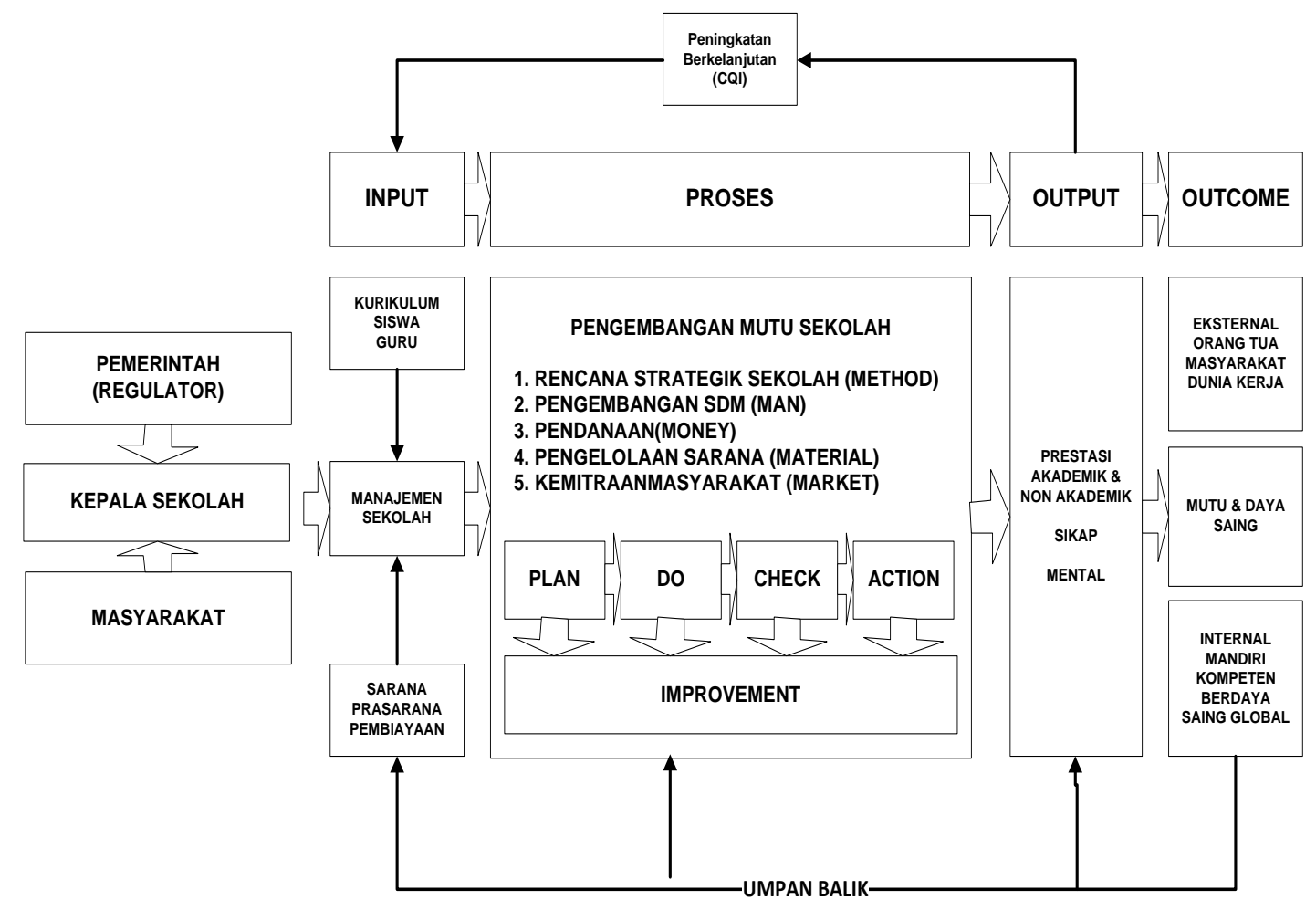

Gambar 3. Model Hipotetik Pengembangan Mutu Sekolah

\section{SIMPULAN DAN REKOMENDASI}

\section{Simpulan}

Berdasarkan data hasil penelitian, diperoleh fakta empirik mengenai kepemimpinan sekolah, fasilitas belajar, pendanaan dan partisipasi masyarakat secara bersama-sama terhadap pengembangan mutu sekolah SMP di Kabupaten Subang. Kondisi empirik pendidikan di Kabupaten Subang menunjukan hasil yang cukup memadai, beberapa aspek dalam penelitian menunjukkan bahwa : (a) Kepemimpinan kepala sekolah pada SMP di Kabupaten Subang sudah sangat memadai, dimensi yang paling menonjol adalah dimensi manajerial, namun dimensi yang paling rendah adalah dimensi supervisi dan inovasi. (b) fasilitas sekolah pada SMP di Kabupaten Subang sudah sangat memadai; (c) pendanaan pendidikan pada SMP di Kabupaten Subang sudah sangat memadai; (d) partisipasi masyarakat pada SMP di Kabupaten Subang sudah sangat memadai; (e) implementasi manajemen stratejik pada SMP di Kabupaten Subang sudah sangat memadai; (f) pengembangan mutu sekolah pada SMP di Kabupaten Subang sudah memadai.

Berdasarkan analisis data penelitian menunjukan pengaruh (sumbangan) masingmasing variabel (a) Kepemimpinan kepala sekolah memberikan pengaruh yang signifikan terhadap implementasi rencana stratejik sekolah; (b) Fasilitas belajar berpengaruh dan signifikan terhadap implementasi rencana stratejik sekolah; (c) Pendanaan berpengaruh dan signifikan terhadap implementasi rencana stratejik sekolah; (d) Partisipasi masyarakat berpengaruh dan signifikan terhadap implementasi rencana stratejik sekolah; (e) Implementasi rencana strategik sekolah memberikan pengaruh yang signifikan terhadap pengembangan mutu sekolah. Implementasi rencana strategik sekolah juga dapat memberikan informasi kepada stakeholder dalam memberikan arahan terhadap upaya pencapaian mutu sekolah yang akan dicapai.

\section{Rekomendasi}

Berdasarkan kesimpulan tersebut di atas, maka dapat disarankankan sebagai berikut:

- Pengembangan mutu sekolah sangat ditentukan oleh kemampuan dan pengetahuan kepala sekolah dalam melakukan pengelolaan segala sumber daya yang dimiliki, disamping itu kepala sekolah hendaknya mampu mengembangkan daya inovasi dan kemampuan pengawasan dalam pelaksanaan pengembangan mutu sekolah. Beberapa upaya yang dapat dilakukan oleh kepala sekolah dengan melakukan benchmarking pada sekolah sejenis, mengikuti pendidikan lanjutan atau diklat teknis, disamping itu 
mencoba melakukan pengembangan bersama staff dalam mengembangkan inovasi dan pengawasan.

- Implementasi rencana stratejik sekolah sangat dipengaruhi oleh ketersediaan sarana dan prasarana pendidikan serta dukungan pendanaan dalam memenuhi semua kebutuhan proses dan program pendidikan, sehingga dibutuhkan kerjasama yang sinergis antara sekolah dalam hal ini kepala sekolah dengan masyarakat dalam memenuhi semua kebutuhan penyelenggaraan pendidikan. Untuk meningkatkan peran serta masyarakat sekolah dapat melibatkan masyarakat dalam setiap kegiatan bahkan masuk dalam pengelolaan pendidikan.

- Pengembangan mutu sekolah sangat berpengaruh terhadap pencapaian pelayanan pendidikan yang efektif dan efisien bagi semua stakeholder sekolah, sehingga penyusunan program dan impelementasinya perlu mendapat dukungan dari semua pemangku kepentingan baik pada level makro, messo maupun mikro.

- Meningkatkan kemampuan manajerial kepala sekolah dalam menyusun rencana stratejik dan melaksanakannya sesuai dengan visi, misi dan tujuan yang telah disusun bersama oleh semua stakeholder sekolah.

- Pemenuhan sarana dan prasarana pendidikan dalam upaya pelaksanaan proses pembelajaran yang terjadi di kelas, sehingga terjadi kegiatan belajar siswa yang dimaksudkan untuk mencapai hasil belajar yang berkualitas.

- Memaksimalkan perencanaan dan pengelolaan pendanaan pendidikan sekolah dalam merencanakan sumber dana dan pertanggungjawaban keuangan untuk menunjang kegiatan pendidikan dan tercapainya tujuan pendidikan di sekolah secara efisien.

- Memaksimalkan peran dan fungsi masyarakat dalam semua kegiatan sekolah yang dirasakan sangat penting keberadaannya, karena bagaimanapun masyarakat adalah wadah yang menyediakan input bagi proses pendidikan pada akhirnya adalah wadah yang akan menampung hasil proses kegiatan pendidikan. Ada banyak kegiatan yang dapat dilakukan dalam keterlibatannya di sekolah, kegiatankegiatan yang dilakukan diarahkan kepada keterlaksanaanya program-program sekolah.

\section{DAFTAR PUSTAKA}

Baker, Michael, (1998) US EPA Office of Environmental Education, Partnership to Support Community-Based Education, Discusion Paper United States Environmental Protection Agency, The University of Wisconsin Cooperative Extension Environmental Resources Center.

Beck, L.G. and Murphy, J. (1996). The Four Imperative of a Successful School. California: Corwin Press, Inc. - A Sage Publications Company

Brown, Mc Namara \& O Hara. (2016). Quality and the rise of value-added in education;

Support Community-Based Education. Discussion Paper Appendix

GuthrieJ (1984) Research views: A program evaluation typology. The Reading Teacher. International Reading Association 37(8): 790-792.

Hunger J. David and Thomas L. Wheelen, (1999), Strategic Management, Addison-Wesley Publishing Co. Massachusetts

Igor, Ansoff \& Edward J. McDonnell (1990), Implanting Strategic Management,.
The Case of Ireland, Jurnal Policy Futures in Education, 14(6), 810-829).

Certo, Samuel C and J.Paul Peter. (2002). The Strategic Management Process, Mc Graw Hill, INC, New York

Cohn, Elchanan (1979). The Economic of Education: An Introduction. Massachussets: Ballinger Pub Company

Conway P and Murphy R (2013) A rising tide meets a perfect storm: new accountabilities in teaching and teacher education in Ireland. Irish Educational Studies 32(1): 11-36.

Greg Wise (1998). An EPA/USDA Partnership to Second Edition. Prentice Hall International.

Jalal, Fasli dan Supriadi Dedi, (2001). Reformasi Pendidikan dalam Konteks Otonomi Daerah, Yogyakarta : Adicitra Karya Nusa

Murphy dan Cleveland, (1991). The Measurement of Work Performance: Methods. Theory, and Application. San Diego: Academic Press Inc 
Nawawi, Hadari, (2003). Kepemimpinan Mengefektifkan Organisasi. Yogyakarta: Gajah Mada University Press

Permadi, Dadi. (1998). Kepemimpinan Mandiri Kepala Sekolah. Bandung: Sarana Panca Karya.

Sloane F, Oloff-Lewis J and Kim SH (2013) Value-added models of teacher and school effectiveness in Ireland: Wise or otherwise? Irish Educational Studies 32(1): 37-67.

Wahyudi, A. S. (1996). Manajemen Strategik. Jakarta: Binarupa Aksara

Wibawa, Basuki. (2005). Pendidikan Teknologi dan Kejuruan (Manajemen dan Implementasinya di Era Otonpmi). Surabaya : Kerja Jaya Medi 